\title{
Peningkatan Pertumbuhan dan Hasil Tanaman Kangkung Darat (Ipomoea reptans Poir) Dengan Pemberian MOL Daun Petai Cina Pada Tanah PMK
}

\author{
Herlina Kurniawati \\ Fakultas Pertanian Universitas Kapuas Sintang \\ e-mail: herlina_kurniawati@yahoo.com
}

\begin{abstract}
Abstrak: Kangkung darat merupakan tanaman yang dapat tumbuh disemua tipe tanah, termasuk tanah PMK. Tanah PMK, selain mempunyai potensi juga mempunyai keterbatasan seperti rendah bahan organik dan rendah unsur hara. Untuk memperoleh hasil kangkung darat yang optimal pada tanah PMK dapat dilakukan dengan menggunakan mikroorganisme lokal atau dikenal dengan istilah MOL. Salah satu jenis MOL yang dapat digunakan sebagai bahan perombak tanah adalah MOL Daun Petai Cina, karena MOL Daun Petai Cina ini mengandung unsur hara N, P, dan K serta unsur hara mikro. Rancangan percobaan yang digunakan dalam penelitian ini dengan menggunakan Rancangan Acak Kelompok (RAK) yang terdiri dari 5 perlakuan dan 5 ulangan. Taraf perlakuan sebagai berikut: Tidak diberi MOL $\left(\mathrm{C}_{0}\right), 50 \mathrm{cc} \mathrm{MOL} / \mathrm{liter}$ air/petak $\left(\mathrm{C}_{1}\right), 100 \mathrm{cc}$ MOL/liter air/petak $\left(\mathrm{C}_{2}\right), 150 \mathrm{cc}$ MOL/liter air/petak $\left(\mathrm{C}_{3}\right)$, dan 200 cc MOL/liter air/petak $\left(\mathrm{C}_{4}\right)$. Data hasil pengamatan dianalisis dengan analisis sidik ragam dan dilanjutkan dengan uji BNJ. Hasil penelitian diketahui bahwa MOL Daun Petai Cina dapat meningkatkan pertumbuhan dan hasil kangkung darat pada tanah PMK, yang terlihat dari hasil pengukuran tinggi tanaman, jumlah daun, dan berat segar tanaman. Pemberian $200 \mathrm{cc}$ MOL Daun Petai Cina menghasilkan pertumbuhan dan hasil kangkung darat tertinggi dengan tinggi rata-rata 29,60 cm per tanaman, 8,60 helai daun per tanaman, dan 35 gram per tanaman.
\end{abstract}

Kata Kunci :, MOL Daun Petai Cina, Kangkung, Pertumbuhan dan hasil, Tanah PMK

\section{PENDAHULUAN}

Tanaman kangkung (Ipomoea reptans Poir) merupakan salah satu jenis tanaman sayuran yang cukup disukai oleh masyarakat, sebagian besar masyarakat menyukai kangkung darat sebagai sayur karena gizi yang terdapat dalam tanaman ini cukup tinggi yaitu vitamin A, kalsium, fosfor, besi dan kalium, kangkung juga mengandung protein, dalam setiap $100 \mathrm{~g}$ mempunyai kandungan air sebesar $91 \%$, protein 32 $\mathrm{g}$, karbohidrat 4,3 g, dan lemak 0,3 g.

Kangkung darat merupakan tanaman yang dapat tumbuh disemua tipe tanah,termasuk tanah PMK asalkan cukup air, Tanah PMK, selain mempunyai potensi juga mempunyai keterbatasan. Hakim, dkk (1986) menjelaskan bahwa keterbatasan tanah PMK pada umumnya adalah miskin unsur hara termasuk unsur hara $\mathrm{N}$, kandungan bahan organik rendah, dan 
kandungan mikroorganisme rendah.

Kendala yang ada pada tanah PMK merupakan salah satu penyebab rendahnya produksi kangkung darat Kabupaten Sintang yaitu, 3,2 ton/ha/tahun (BPS Kabupaten Sintang, 2014).

Langkah untuk memperoleh hasil kangkung darat pada tanah PMK yang optimal dapat dilakukan dengan menggunakan bahan perombak tanah dengan memanfaatkan mikroorganisme seperti menggunakan mikro-organisme lokal atau dikenal dengan istilah MOL. Salah satu jenis MOL yang dapat digunakan sebagai bahan perombak tanah adalah MOL Daun Petai Cina, karena MOL Daun Petai Cina ini mengandung unsur hara $\mathrm{N}, \mathrm{P}$, dan $\mathrm{K}$ sertaunsur hara mikro selain menggandung unsur hara, juga mengandung mikroorganisme.

Penelitian ini bertujuan untuk 1) mengetahui pengaruh pemberian MOL Daun Petai Cina terhadap pertumbuhan dan hasil kangkung darat pada tanah PMK, 2) mengetahui dosis pemeberian MOL Daun Petai Cina yang akan meningkatkan pertumbuhan dan hasil kangkung darat.

\section{METODOLOGI PENELITIAN}

Rancangan percobaan yang digunakan dalam penelitian ini dengan menggunakan Rancangan Acak Kelompok (RAK) yang terdiri dari 5 perlakuan dan 5 ulangan. Adapun perlakuan penelitian sebagai berikut : $\mathrm{C}_{0}=$ Kontrol (Tidak diberi MOL Daun Petai Cina), $\mathrm{C}_{1}=50 \mathrm{cc}$ MOL Daun Petai Cina /liter air/petak, $\mathrm{C}_{2}=100 \mathrm{cc}$ MOL Daun Petai Cina /liter air/petak, $\mathrm{C}_{3}=150 \mathrm{cc}$ MOL Daun Petai Cina /liter air/petak, $\mathrm{C}_{4}=200 \mathrm{cc}$ MOL Daun Petai Cina /liter air/petak.

Jumlah satuan percobaan dalam penelitian ini adalah 5 taraf perlakuan $\mathrm{x}$ 5 ulangan x16 tanaman $=400$ tanaman . Satuan pengamatan diambil sebanyak 4 tanaman $\times 5$ perlakuan $\times 5$ ulangan $=$ 100 tanaman.

\section{Bahan dan Alat Penelitian}

Bahan-bahan yang digunakan dalam penelitian adalah benih kangkung darat varietas Bisi, MOL Daun Petai Cina, pupuk kandang kotoran ayam sebagai pupuk dasar, air digunakan untuk menyirami tanaman dan untuk mencampur dosis MOL yang akan di aplikasikan ke tanaman.

Alat-alat yang digunakan dalam penelitian ini antara lain parang, 
Peningkatan Pertumbuhan dan Hasil Tanaman Kangkung Darat (Ipomoea reptans Poir) Dengan Pemberian MOL Daun Petai Cina Pada Tanah PMK

cangkul, timbangan, ember, gayung dan gembor, meteran dan mistar, kamera, kayu dan papan, alat-alat tulis, gelas ukur, alat semprot.

\section{Waktu dan tempat penelitian}

Penelitian dilaksanakan di Desa Baning Kota, Kecamatan Sintang, Kabupaten Sintang. Penelitian akan dilaksanakan mulai bulan Januari sampai Maret 2018.

\section{HASIL DAN PEMBAHASAN}

\section{Hasil Penelitian}

\section{Tinggi Tanaman}

Hasil pengamatan pengaruh perlakuan yang telah direratakan ditampilkan dalam Tabel 1 dan hasil analisis ragam dalam Tabel 2.

Tabel 1. Rerata hasil pengamatan tinggi tanaman $(\mathrm{cm})$

\begin{tabular}{|c|c|c|c|c|c|c|c|}
\hline \multirow{2}{*}{ Perlakuan } & \multicolumn{5}{|c|}{ Ulangan } & \multirow{2}{*}{ Jumlah } & \multirow{2}{*}{ Rerata } \\
\hline & I & II & III & IV & $\mathbf{V}$ & & \\
\hline $\mathrm{C}_{0}$ & 14,25 & 15,00 & 15,00 & 18,00 & 20,25 & 82,50 & 16,50 \\
\hline $\mathrm{C}_{1}$ & 16,00 & 19,25 & 20,75 & 20,50 & 22,25 & 98,75 & 19,75 \\
\hline $\mathrm{C}_{2}$ & 17,25 & 20,00 & 25,00 & 25,25 & 25,50 & 113,00 & 22,60 \\
\hline $\mathrm{C}_{3}$ & 23,00 & 23,75 & 28,50 & 29,00 & 28,50 & 132,75 & 26,55 \\
\hline $\mathrm{C}_{4}$ & 28,75 & 28,25 & 29,00 & 31,25 & 30,75 & 148,00 & 29,60 \\
\hline Total & 99,25 & 106,25 & 118,25 & 124,00 & 127,25 & 575,00 & 23,00 \\
\hline
\end{tabular}

Sumber: Data hasil pengamatan, 2018.

Rerata hasil pengamatan tanaman yang diberi $200 \mathrm{cc}$ lebih tinggi, pengaruh pemberian MOL Daun Petai sedangkan tanaman yang terendah pada Cina terhadap tinggi tanaman seperti yang tidak diberi MOL. yang terlihat dalam Tabel 1, bahwa

Tabel 2. Analisis ragam tinggi tanaman $(\mathrm{cm})$

\begin{tabular}{lcccccc}
\hline \multirow{2}{*}{ SK } & \multirow{2}{*}{ DB } & \multirow{2}{*}{ JK } & \multirow{2}{*}{ KT } & \multirow{2}{*}{ F hitung } & \multicolumn{2}{c}{ F tabel } \\
\cline { 6 - 7 } & & & & & $\mathbf{0 , 0 5}$ & $\mathbf{0 , 0 1}$ \\
\hline Ulangan & 4 & 113,25 & 28,31 & $14,01^{* * *}$ & 2,78 & 4,22 \\
Perlakuan & 4 & 545,67 & 136,42 & $67,52^{* *}$ & 2,78 & 4,22 \\
Galat & 16 & 32,33 & 2,02 & & & \\
\hline Total & $\mathbf{2 4}$ & $\mathbf{6 9 1 , 2 5}$ & & $\mathbf{k k}=\mathbf{6 , 1 8 \%}$ & \\
\hline
\end{tabular}

Sumber : Hasil analisis data, 2018.

Keterangan $\quad: * *=$ pengaruh sangat nyata pada taraf 0,01 
Peningkatan Pertumbuhan dan Hasil Tanaman Kangkung Darat (Ipomoea reptans Poir) Dengan Pemberian MOL Daun Petai Cina Pada Tanah PMK

Hasil analisis ragam seperti yang tertera dalam Tabel 2. memperlihatkan bahwa perlakuan MOL Daun Petai Cina berpengaruh nyata terhadap tinggi tanaman. Selanjutnya agar diketahui taraf pemberian yang menunjukkan tinggi tanaman tertinggi dilakukan dengan uji BNJ (Tabel 3).

Tabel 3. Uji BNJ pemberian MOL Daun Petai Cina terhadap tinggi tanaman (cm)

\begin{tabular}{rccccc}
\hline Perlakuan & Rerata & \multicolumn{5}{c}{ Beda } \\
\hline $\mathrm{C}_{0}$ & $16,50 \mathrm{a}$ & - & & \\
$\mathrm{C}_{1}$ & $19,75 \mathrm{~b}$ & $3,25^{* *}$ & - & & \\
$\mathrm{C}_{2}$ & $22,60 \mathrm{c}$ & $6,10^{* *}$ & $2,85^{* *}$ & - & \\
$\mathrm{C}_{3}$ & $26,55 \mathrm{~d}$ & $10,05^{* *}$ & $6,80^{* *}$ & $3,95^{* *}$ & - \\
$\mathrm{C}_{4}$ & $29,60 \mathrm{e}$ & $13,10^{* *}$ & $9,85^{* *}$ & $7,00^{* *}$ & $3,05^{* *}$ \\
\hline BNJ 0,05 & $=$ & $\mathbf{1 , 1 5}$ & BNJ 0,01 = $\mathbf{1 , 4 8}$ & \\
\hline
\end{tabular}

Sumber : Hasil analisis data, 2018.

Keterangan $\quad: * *=$ beda sangat nyata pada taraf 0,01

Uji BNJ dalam Tabel 3 menunjukkan tiap peningkatan dosis pemberian MOL Daun Petai Cina disertai dengan meningkatnya tinggi tanaman. Tanaman yang paling tinggi pada pemberian $200 \mathrm{cc}$ dengan rata-rata tinggi tanaman 29,60 cm per tanaman.

\begin{abstract}
Jumlah Daun
Hasil pengamatan pengaruh MOL Daun Petai Cina terhadap jumlah daun diperlihatkan dalam Lampiran 5, rerata hasil pengamatan per tanaman disajikan dalam Tabel 4 dan analis sidak ragam ditampilkan pada Tabel 5.
\end{abstract}

Tabel 4. Rerata jumlah daun per tanaman (helai)

\begin{tabular}{|c|c|c|c|c|c|c|c|}
\hline \multirow{2}{*}{ Perlakuan } & \multicolumn{5}{|c|}{ Ulangan } & \multirow{2}{*}{ Jumlah } & \multirow{2}{*}{ Rerata } \\
\hline & I & II & III & IV & $\mathbf{V}$ & & \\
\hline $\mathrm{C}_{0}$ & 6,75 & 6,50 & 7,00 & 6,75 & 6,75 & 33,75 & 6,75 \\
\hline $\mathrm{C}_{1}$ & 7,00 & 7,25 & 7,25 & 7,75 & 7,50 & 36,75 & 7,35 \\
\hline $\mathrm{C}_{2}$ & 7,50 & 7,25 & 8,00 & 8,25 & 7,25 & 38,25 & 7,65 \\
\hline $\mathrm{C}_{3}$ & 7,75 & 8,00 & 7,50 & 8,75 & 8,00 & 40,00 & 8,00 \\
\hline $\mathrm{C}_{4}$ & 8,00 & 8,25 & 8,50 & 9,50 & 8,75 & 43,00 & 8,60 \\
\hline Total & 37,00 & 37,25 & 38,25 & 41,00 & 38,25 & 191,75 & 7,67 \\
\hline
\end{tabular}

Sumber : Data hasil pengamatan, 2018. 
Tabel 5. Analisis ragam jumlah daun (helai)

\begin{tabular}{lcccccc}
\hline \multirow{2}{*}{ SK } & \multirow{2}{*}{ DB } & \multirow{2}{*}{ JK } & \multirow{2}{*}{ KT } & \multirow{2}{*}{ F hitung } & \multicolumn{2}{c}{ F tabel } \\
\cline { 6 - 7 } & & & & & $\mathbf{0 , 0 5}$ & $\mathbf{0 , 0 1}$ \\
Ulangan & 4 & 2,01 & 0,50 & $5,52^{* * *}$ & 2,78 & 4,22 \\
Perlakuan & 4 & 9,62 & 2,40 & $26,34^{* *}$ & 2,78 & 4,22 \\
Galat & 16 & 1,46 & 0,09 & & & \\
\hline Total & $\mathbf{2 4}$ & $\mathbf{1 3 , 0 9}$ & & Kk $=\mathbf{3 , 9 4 \%}$ & \\
\hline
\end{tabular}

Sumber : Hasil analisis data, 2018.

Keterangan $\quad: * *=$ pengaruh sangat nyata pada taraf 0,01

Hasil analisis ragam yang terlihat dalam Tabel 5 menunjukkan bahwa perlakuan MOL Daun Petai Cina berpengaruh sangat nyata terhadap ratarata jumlah daun per tanaman.
Selanjutnya untuk mengetahui taraf pemberian yang menghasilkan jumlah daun tertinggi dilanjutkan dengan uji BNJ yang hasilnya seperti pada Tabel 6 .

Tabel 6. Uji BNJ pemberian MOL Daun Petai Cina terhadap jumlah daun per tanaman (helai)

\begin{tabular}{cccccc}
\hline Perlakuan & Rerata & \multicolumn{3}{c}{ Beda } \\
\hline $\mathrm{C}_{0}$ & $6,75 \mathrm{a}$ & - & & & \\
$\mathrm{C}_{1}$ & $7,35 \mathrm{~b}$ & $0,60^{* * *}$ & - & & \\
$\mathrm{C}_{2}$ & $7,65 \mathrm{c}$ & $0,90^{* *}$ & $0,30^{*}$ & - & - \\
$\mathrm{C}_{3}$ & $8,00 \mathrm{~d}$ & $1,25^{* *}$ & $0,65^{* *}$ & $0,35^{* *}$ & - \\
$\mathrm{C}_{4}$ & $8,60 \mathrm{e}$ & $1,85^{* *}$ & $1,25^{* *}$ & $0,95^{* *}$ & $0,60^{* *}$ \\
\hline
\end{tabular}

BNJ 0,05 = 0,24

BNJ 0,01 =0,31

Sumber : Hasil analisis data, 2018.

Keterangan $\quad: * *=$ beda sangat nyata pada taraf 0,01

Hasil uji BNJ menunjukkan bahwa jumlah daun meningkat beriringan dengan taraf pemberian MOL Daun Petai Cina, semakin tinggi dosis diberikan jumlah daun yang dihasilkan oleh tanaman juga semakin banyak. Pada Tabel 6 diperlihatkan bahwa pemberian $200 \mathrm{cc}$ menghasilkan jumlah daun rata-rata 8,60 helai. Selisih rata-rata jumlah daun yang dihasilkan dari tanaman yang diberi 150 cc 0,60 helai, 0,95 helai daun dengan daun tanaman ynag diberi $100 \mathrm{cc}, 1,25$ daun dengan tanaman yang diberi $50 \mathrm{cc}$,dan 1,85 daun dari tanaman yang tidak diberi MOL. 
Peningkatan Pertumbuhan dan Hasil Tanaman Kangkung Darat (Ipomoea reptans Poir) Dengan Pemberian MOL Daun Petai Cina Pada Tanah PMK

\section{Berat Segar}

Hasil rerata berat segar per tanaman disajikan dalam Tabel 7 dan analisis ragam disajikan pada Tabel 8 .

Tabel 7. Rerata berat segar per tanaman $(\mathrm{g})$

\begin{tabular}{|c|c|c|c|c|c|c|c|}
\hline \multirow{2}{*}{ Perlakuan } & \multicolumn{5}{|c|}{ Ulangan } & \multirow{2}{*}{ Jumlah } & \multirow{2}{*}{ Rerata } \\
\hline & I & II & III & IV & $\mathbf{V}$ & & \\
\hline $\mathrm{C}_{0}$ & 5,00 & 5,50 & 7,50 & 10,00 & 10,00 & 38,00 & 7,60 \\
\hline $\mathrm{C}_{1}$ & 10,00 & 10,00 & 12,50 & 15,00 & 15,00 & 62,50 & 12,50 \\
\hline $\mathrm{C}_{2}$ & 15,00 & 12,50 & 20,00 & 22,50 & 20,00 & 90,00 & 18,00 \\
\hline $\mathrm{C}_{3}$ & 30,00 & 15,00 & 25,00 & 25,00 & 22,50 & 117,50 & 23,50 \\
\hline $\mathrm{C}_{4}$ & 50,00 & 30,00 & 27,50 & 32,50 & 35,00 & 175,00 & 35,00 \\
\hline Total & 110,00 & 73,00 & 92,50 & 105,00 & 102,50 & 483,00 & 19,32 \\
\hline
\end{tabular}

Tabel 8. Analisis ragam berat segar tanaman $(\mathrm{g})$

\begin{tabular}{lcccccc}
\hline \multirow{2}{*}{ SK } & \multirow{2}{*}{ DB } & \multirow{2}{*}{ JK } & \multirow{2}{*}{ KT } & F hitung & $\mathbf{0 , 0 5}$ & $\mathbf{0 , 0 1}$ \\
\hline Ulangan & 4 & 171,74 & 42,93 & $1,83^{\text {tn }}$ & 2,78 & 4,22 \\
Perlakuan & 4 & 2244,74 & 561,19 & $23,88^{* *}$ & 2,78 & 4,22 \\
Galat & 16 & 375,96 & 23,50 & & & \\
\hline Total & $\mathbf{2 4}$ & $\mathbf{2 7 9 2 , 4 4}$ & & $\mathbf{k k}=\mathbf{2 5 , 0 9 \%}$ & \\
\hline
\end{tabular}

Sumber : Hasil analisis data, 2018.

Keterangan $:$ tn $=$ pengaruh tidak nyata pada taraf 0,05 $* *=$ pengaruh sangat nyata pada taraf 0,01

Hasil analisa ragam seperti terlihat dalam Tabel 8 diketahui bahwa pemberian MOL Daun Petai Cina berpengaruh nyata terhadap berat segar tanaman. Selanjutnya untuk mengetahui taraf pemberian MOL Daun Petai Cina yang menghasilkan berat segar rata-rata tertinggi per tanaman dilakukan dengan uji BNJ seperti pada Tabel 9. 
Peningkatan Pertumbuhan dan Hasil Tanaman Kangkung Darat (Ipomoea reptans Poir) Dengan Pemberian MOL Daun Petai Cina Pada Tanah PMK

Tabel 9. Uji BNJ pemberian MOL Daun Petai Cina terhadap berat segar tanaman per tanaman $(\mathrm{g})$

\begin{tabular}{cccccc}
\hline Perlakuan & Rerata & \multicolumn{3}{c}{ Beda } \\
\hline $\mathrm{C}_{0}$ & $7,60 \mathrm{a}$ & - & & & \\
$\mathrm{C}_{1}$ & $12,50 \mathrm{~b}$ & $4,90^{*}$ & - & - & \\
$\mathrm{C}_{2}$ & $18,00 \mathrm{c}$ & $10,40^{* *}$ & $5,50^{* *}$ & $^{* *}$ & - \\
$\mathrm{C}_{3}$ & $23,50 \mathrm{~d}$ & $15,90^{* *}$ & $11,00^{* *}$ & $5,50^{* *}$ & $11,50^{* *}$ \\
$\mathrm{C}_{4}$ & $35,00 \mathrm{e}$ & $27,40^{* *}$ & $22,50^{* *}$ & $17,00^{* *}$ & \\
\hline BNJ 0,05 = 3,93 & & & BNJ 0,01 =5,03
\end{tabular}

Sumber : Hasil analisis data, 2018.

Keterangan $: * *=$ beda sangat nyata pada taraf 0,01 
Hasil uji BNJ seperti yang terlihat dalam Tabel 9 bahwa berat segar tanaman mengikuti taraf pemberian MOL Daun Petai Cina. Semakin tinggi dosis diberikan, berat tanaman juga tinggi.

\section{Pembahasan}

Hasil analisis data diketahui bahwa pemberian MOL Daun Petai Cina berpengaruh nyata terhadap pertumbuhan dan hasil tanaman. Hal ini disebabkan karena dengan pemberian MOL hara menjadi tersedia bagi tanaman sehingga perbanyakan, pertambahan ukuran, dan jumlah sel dalam tanaman berlangsung secara optimal.

Peningkatan Pertumbuhan dan Hasil Tanaman Kangkung Darat (Ipomoea reptans Poir) Dengan Pemberian MOL Daun Petai Cina Pada Tanah PMK

kacang panjang dengan berat 0,76 kg. Menurut Leiwakabessy dan Sutandi (2004), unsur hara merupakan zat yang diserap tanaman yang mempengaruhi pertumbuhan dan produksi tanaman. Hara yang diserap oleh tanaman dapat berupa kation maupun anion. Kebutuhan unsur hara bersifat mutlak bagi setiap tanaman dan tidak dapat digantikan oleh unsur yang lain dengan kadar yang berbeda sesuai jenis tanamannya sebab jika kekurangan unsur hara akan menghambat pertumbuhan tanaman itu sendiri. Gardner, dkk (1991) menyatakan bahwa ketersediaan unsur hara merupakan salah satu faktor lingkungan yang sangat menentukan laju pertumbuhan tanaman.

Hasil uji BNJ diketahui bahwa semakin banyak MOL Daun Petai Cina diberikan

$29,60 \mathrm{~cm}$ per tanaman, jumlah daun rata-rata 8,60 hela1, dan rata-rata berat tanaman segar 35 gram per tanaman. Hal ini diduga disebabkan sifat dari MOL yang merupakan salah satu jenis pupuk organik dengan kandungan hara yang rendah, sehingga dengan pemberian pada dosis rendah pengaruh terhadap pertumbuhan maupun hasil tanaman juga rendah demikian juga sebaliknya jika pemberian dalam jumlah yang banyak pertumbuhan maupun hasil tanaman tinggi. Hardjowigeno (2003) mengemukakan bahwa salah satu kelemahan dari pemberian bahan-bahan organik adalah kandungan hara yang rendah serta pengaruh terhadap tanaman sangat lamban.

Pemberian MOL Daun Petai Cina 200 cc menghasilkan pertumbuhan dan hasil tanaman tertinggi disebabkan karena kandungan mikroorganisme yang dapat 
memfermentasikan bahan organik sehingga menghasilkan senyawa yang dapat diserap langsung oleh tanaman. Arinong dan Lasiwua (2011) menyatakan bahwa mikroorganisme yang diinokulasikan dalam bahan dasar bekerjasama memperbaiki tingkat kesuburan tanaman dengan cara mengikat nitrogen dari udara bebas, mengkonsumsi gas beracun. Hasil fermentasi bahan tersebut menjadi senyawa organik yang dapat diserap oleh tanaman, menghasilkan senyawa antibiotik yang bersifat toksik terhadap patogen/penyakit dan melarutkan ion fosfat dan ion mikro lainnya (Wididana, 1996). Lebih lanjut Lingga (1995), menyatakan bahwa tanah yang berstruktur baik, dengan kata lain tanah yang banyak mengandung mikroorganisme dan kepadatan tanah yang kurang dapat menunjang pertumbuhan akar menembus tanah melalui pori-pori tanah sehingga dapat menyerap air dan unsur hara yang terlarut.

Meningkatnya pertumbuhan dan hasil tanaman sebagai akibat dari pengaruh pemberian MOL Daun Petai Cina, karena ketersediaan dan serapan unsur hara yang

Peningkatan Pertumbuhan dan Hasil Tanaman Kangkung Darat (Ipomoea reptans Poir) Dengan Pemberian MOL Daun Petai Cina Pada Tanah PMK

dikemukakan oleh Harjadi (1995) bahwa hasil metabolisme (karbohidrat, protein dan lipida) digunakan tanaman untuk keperluan pembentukan dan pem-besaran sel tanaman. Selanjutnya dijelaskan oleh Dwidjoseputro (1992) bahwa tanaman akan tumbuh subur dan memberikan hasil yang baik jika unsur hara yang dibutuhkannya tersedia dalam jumlah cukup dan seimbang.

\section{KESIMPULAN DAN SARAN}

\section{Kesimpulan}

Hasil analisis data dalam penelitian ini diambil kesimpulan sebagai berikut:

1. Pemberian MOL Daun Petai Cina berpengaruh terhadap pertumbuhan dan hasil kangkung darat pada tanah PMK, yang terlihat dari hasil pengukuran tinggi tanaman, jumlah daun, dan berat segar tanaman.

2. Pemberian 200 cc MOL Daun Petai Cina menghasilkan pertumbuhan dan hasil kangkung darat tertinggi dengan tinggi rata-rata 29,60 $\mathrm{cm}$ per tanaman, 8,60 helai daun per tanaman, dan 35 gram per tanaman.

\section{Saran}


Melalui hasil penelitian ini disarankan untuk:

1. Memberikan MOL Daun Petai Cina dalam budidaya kangkung darat pada tanah PMK dengan dosis 200 cc per liter air agar pertumbuhan dan hasil menjadi meningkat.

2. Perlu dilakukan penelitian lanjutan dengan menggunakan dosis diatas $200 \mathrm{cc}$ MOL Daun Petai Cina agar diperoleh pertumbuhan dan hasil kangkung darat yang optimal pada tanah PMK.

275

PIPER No.26 Volume 14 April 2018

AAK. 1983. Dasar-Dasar Bercocok Tanaman. Yogyakarta. Kanisius.

Arinong, A.R., dan C. D. Lasiwua. 2011. Aplikasi Pupuk Organik Cair Terhadap Pertumbuhan Dan Produksi Tanaman Sawi. Jurnal Agrisistem, Juni 2011, Vol. 7 No. 1. Hal:47-54.

Dwidjoseputro, D. 1992. Pengantar Fisiologi Tumbuhan. Jakarta. Gramedia Pustaka Utama.

Gardner, F.P., Pearce, R.B., dan Mitchell,R.L. 2001. Diterjemahkan oleh Herawati, S. Fisiologi Tumbuhan Budidaya. Jakarta. Universitas Indonesia Press.

Gasperz, V. 1999. Metode Perancangan Percobaan. Bandung. Amirco.

Hakim, N., Nyakpa, Y.n., Lubis A,M., Sutopo, G.N., Saul. M.R., Diha, M.A., Go Ban Hon, dan Bailey. 1986. Dasar-Dasar Ilmu Tanah. Lampung. Universitas Lampung.

Peningkatan Pertumbuhan dan Hasil Tanaman Kangkung Darat (Ipomoea reptans Poir) Dengan Pemberian MOL Daun Petai Cina Pada Tanah PMK

Kurniawati, H. 2017. Pengaruh MOL Bekicot Terhadap Hasil Kacang Panjang (Vigna sinensis, L.) Pada Tanah Podsolik Merah Kuning. Sintang. Jurnal PIPER Fakultas Pertanian Universitas Kapuas Sintang. Nomor 25 Volume 13. Hal. 122129.

Lakitan, B. 2001. Dasar-Dasar Fisiologi Tumbuhan. Jakarta. Raja Grafindo Persada.

Leiwakabessy, F.M. dan A. Sutandi. 2004. Pupuk dan Pemupukan. Bogor. Departemen Ilmu Tanah. Fakultas Pertanian. Institut Pertanian Bogor.

Lingga, P. 1995. Petunjuk Penggunaan Pupuk. Jakarta. Penerbit Swadaya.

Rukmana, R. 1986. Bertanam Kangkung. Yogyakarta. Kanisus 
Setyamidjaya. 2003. Pupuk dan Cara Pemupukan. Jakarta. Penebar Swadaya.

Sunaryono, H. 1984. Kunci Bercocok Tanam Sayur-Sayuran Penting Di Indonesia. Bandung. Sinar Baru.

Susestya. 2008. Petunjuk Lengkap Membuat Pupuk Organik. Yogyakarta. Pustaka Baru Press.

Sutanto. 2003. Pertanian Organik. Jakarta. Gramedia Pustaka Utama.

Sutejo, M.M. 2005 Pupuk dan Cara Pemupukan. Jakarta. Rineka Cipta.

Wididana. G.N. 1996. Tanya Jawab Efektif Mikroorganisme. Jakarta. Koperasi Karyawan Departemen Kehutanan. 